\title{
|| Mentorluk Becerileri Değerlendirme Aracının (MEBDA) Geliştirilmesi
}

\author{
Berna ASLAN* \\ Çağlayan DiNÇER ${ }^{* *}$ \\ Gönül AKÇAMETE***
}

\begin{abstract}
Öz: Araştırmada uygulama öğretmenlerinin mentorluk becerilerini belirlemek amaciyla Mentorluk Becerileri Değerlendirme Aracı (MEBDA) geliştirilmiş ve ölçme aracının psikometrik özellikleri incelenmiştir. Çalışmanın ilk aşamasında, 66 maddeden oluşan araç birinci çalışma grubundaki 202 öğretmen adayına uygulanmış ve yapılan Açımlayıcı Faktör Analizi (AFA) sonuçları doğrultusunda madde-toplam test korelasyonu (ayırt ediciliği) .45 değerinin altında olan 25 madde araçtan çıarılmıştır. AFA sonucuna göre 41 maddeden oluşan araç ikinci çalışma grubundaki 232 öğretmen adayına uygulanmış ve Doğrulayıcı Faktör Analizi (DFA) yapılmıştır. AFA sonucunda aracın üç boyutlu bir yapıda olduğu belirlenmiştir. Öğrenme öğretme süreci, iletişim süreci ve mesleki gelişim süreci olmak üzere üç boyuttan oluşan aracın birinci alt boyutundaki maddelerinin aracın \%23'ünü açıkladığı ve diğer iki alt boyutun her birinin ölçme aracındaki maddelerin \%18'ini açıkladığı bulunmuştur. DFA sonucunda araç maddelerinin t değerleri 0.01 düzeyinde anlamlı olduğu için analiz dışı bırakılan bir madde olmamıştır. Ayrıca MEBDA'nın CFI ve NNFI değerleri 97 olduğundan modelin iyi uyum gösterdiği söylenebilir.
\end{abstract}

Anahtar Sözcükler: Mentorluk, Uygulama Öğretmeni, Mentorluk Becerileri Değerlendirme Aracı (MEBDA)

\section{Developing the Mentoring Skills Assessment Tool}

\begin{abstract}
In this research the Mentoring Skills Assessment Tool was developed, and the psychometric features of the tool were investigated. At the first stage, a tool with 66 items was applied to 202 teacher candidates and an Exploratory Factor Analysis (EFA) was conducted. As a result of the EFA, items having a low discrimination level (lower than .45), were omitted from the tool. A tool with 41 items was applied to 232 teacher candidates, and a Confirmatory Factor Analysis (CFA) was calculated. As a result of the EFA it was found that the tool has three dimensions: teaching-learning process, communication process and professional development process. The teaching-learning process dimension makes up $23 \%$ of the total tool and each of the other dimensions make up $18 \%$ of the tool. As a result of the CFA, $t$ values of all the items are significant at a 0.01 level and none of the items were omitted or changed. Also, CFI and NNFI values were .97 and this shows us that the tool is coherent and suitable for assessing mentoring skills.
\end{abstract}

Keywords: Mentoring, Practice Teacher, Mentoring Skills Assessment Tool

* Ankara Üniversitesi, Eğitim Bilimleri Fakültesi, Eğitim Bilimleri Bölümü Eğitim Programları ve Öğretim ABD, Ankara, Türkiye, e-posta: baslan@ankara.edu.tr, ORCID: https://orcid.org/0000-0002-0967-3274

**Hasan Kalyoncu Üniversitesi, Eğitim Fakültesi, Temel Eğitim Bölümü Okul Öncesi Eğitimi ABD, Gaziantep, Türkiye, e-posta: caglayan.dincer@hku.edu.tr, ORCID: https://orcid.org/0000-0001-5468-9155

*** Yakındoğu Üniversitesi, Atatürk Eğitim Fakültesi, Özel Eğitim Bölümü, Lefkoşa, KKTC, e-posta: gonul.akcamete@neu.edu.tr, ORCID: https://orcid.org/0000-0002-2964-514X 
Öğretmenlik, genel kültür ile birlikte alan bilgisi ve mesleki bilgi ve becerileri içeren zor ve karmaşık bir meslektir. Öğretmenlik mesleğine ilişkin genel yeterlikler (Milli Eğitim Bakanlığı [MEB], 2017) incelendiğinde bu yeterliklerin kazandırılabilmesi için lisans eğitimi sürecindeki öğretmenlik uygulaması derslerinin kritik öneme sahip olduğu görülmektedir. Öğretmenlik uygulaması dersleri, öğretmen adaylarının mesleğin gerektirdiği bilgi ve becerileri bütüncül olarak deneyimlenebilmesine olanak sağlayan derslerdir. Bu nedenle bu derslerin okullardaki uygulama süreçleri iyi tasarlanmalı ve ciddiyetle yürütülmelidir. MEB tarafından yayımlanan öğretmenlik uygulanması yönergesinde (MEB, 1998) uygulama öğretmenlerinin “öğretmen adaylarına mesleğin gerektirdiği davranışları kazanmasında rehberlik ve danışmanlık yapan sınıf ya da ders öğretmeni" (m. 4) olarak tanımlanmaktadır. Bu tanıma göre uygulama öğretmenlerinden beklenen iş ve sorumluluklara bakıldığında uygulama öğretmenlerinin mentorluk ile ilgili bilgi, beceri ve yetkinliklere sahip olması gerektiği görülmektedir.

Mentorluk bireylerin, bir mesleği ya da işi daha iyi yapmalarında gerekli bilgi ve beceriye sahip olan deneyimli bireyler tarafından onlara rehberlik edilmesi ve yol gösterilmesi olarak kabul edilebilir (Searby ve Tripses, 2012). Kısaca mentorluk uygulaması, mesleğe yeni başlayan kişilere mesleğin gereklerini öğrenmesi sürecinde destek verme işlemidir. Bu sürecin etkili ve verimli olabilmesi mentor olarak görev yapacak kişilerin mentorluk görevinin gereklerini iyi bilmesinin yanı sıra görev ve sorumluluklarını yerine getirebilmesine de bağlıdır. Bir mesleğin gelişmesinde o mesleğe ilişkin bilgi birikimlerinin gelecek kuşaklara aktarılması ve mesleğe yeni başlayanlara gerekli desteğin verilmesi oldukça önemlidir. Mentorluk sistemi bu amaçla oldukça etkili kullanılabilir (Aslan ve Öcal, 2012; Stephenson, 2009). Mentorluk uygulamalarının temel amacı, bireylere kişisel gelişim hedefleri doğrultusunda bilgi ve yeteneklerini geliştirme imkanı sunmaktır (Crispi ve Cruz, 2009, s. 536). Çünkü mentorluk bugüne ve geleceğe odaklı bir süreçtir. Önceki bilgiler bugüne ve geleceğe şekil vermek için kullanılır. Mentor olan kişi, daha önceki deneyimlerini ve bilgisini o yolu takip edecek olan ve onun rehberliğine ihtiyaç duyan, onu model alacak kişiye aktarır. Mentorluk özellikle, mesleğin ilk yıllarında ve kritik dönemlerde çok önem taşımaktadır. Mentorların, danışan kişiye yani deneyimsiz öğretmene mesleğine ilişkin gerekli bilgi, tavsiye ve desteği sağlaması gerekir. Bununla birlikte mentorluğu üstlenen kişinin istekliliği, danışan kişiye destek ve cesaret vererek model olması da bu süreçte çok önemlidir (Daloz, 1999, akt. Searby ve Tripses, 2012).

Monkeviciene ve Autukeviciene (2015) tarafından yapılan araştırmada, mentorluğun, en etkili öğretmen eğitimi stratejilerinden birisi olduğu vurgulanmıştır. Awaya ve diğerleri (2003) aday öğretmen-uygulama öğretmeni ilişkisinden farklı olarak mentor- aday öğretmen ilişkisinin bir süreç (yolculuk) olduğunu, ilişkilerin eşit olduğunu, mentorun pratik bilgiler veren bir rehber, moral desteği kaynağı ve aday öğretmene kendini keşfetme olanağı tanıyan kişi olduğunu belirtmektedir. Çeşitli kaynaklardaki mentorluk tanımlarına baktığımızda (Anderson ve Shannon, 1988; Daresh, 2003) tanımlardaki ortak vurguların mentorluğun bir süreç olduğu ve bu süreçte meslekteki daha deneyimli kişilerin rol model olduğu yönündedir. Ayrıca mentor olmak, sadece deneyimleri paylaşmak demek değildir, mentorlukta dinlemek ve öğrenmek sorumluluğuna da vurgu yapılmaktadır (Cain, 2009; Daresh, 2003). Cain (2009), mentorluğa ilişkin tanımların daha çok ideal olanı yansıttığını ve özellikle öğretmen eğitimi sürecinde deneyimsiz öğretmenlerin uygulamaya gidilen okullardaki uygulama öğretmelerine güvendiğini belirtmiştir. Smith (2007, s. 277), mentorluğu "mentorun yalnızca deneyimsiz öğretmeni desteklemeyeceği, aynı zamanda ilerlemenin sağlanması için üretken olmaya zorladığı" öğrenme biçimi olarak tanımlamaktadır. Bununla birlikte Fairbanks, Freedman ve Kahn (2000, s. 103) öğretmen eğitiminde mentorluğu "mentor öğretmenlerin ve aday öğretmenlerin çeşitli mesleki amaçlara ulaşmak için, karşılaştıkları bağlamsal faktörlere cevap olarak oluşturdukları ve müzakere ettikleri karmaşık sosyal etkileşimler" olarak tanımlamaktadır (Ambrosetti ve Dekkers, 2010).

Mentorluk, tüm bunların yanı sıra kişilerarası yoğun bir ilişki olarak tanımlanmakla birlikte mentorluğun kişiyi sadece bir yönüyle değil, bütün olarak geliştiren bir süreç olduğu belirtilmektedir (Higgins ve Kram, 2001; Smith, 2007). Fletcher (2000), mentor ile deneyimsiz öğretmen arasındaki ilişkinin önemli olduğunu vurgulamış ve "iyi bir mentor olmak için kişisel ve mesleki katılım gereklidir" diye belirtmiştir. Kwan ve Lopez-Real (2005, s.276) mentorluğu “hem ilişki hem de süreç" olarak görmektedir. Bununla birlikte Fairbanks ve diğerleri (2000) tarafından özetlenen bağlam, mentorluğun kilit parçasıdır. Ancak, literatürdeki çoğu tanım, 
mentorluğun üç bileşeninin (ilişki, süreç ve bağlam) tümünü dikkate almaz. Lai (2005) üç bileşeni boyutsal olarak tanımlamaktadır - ilişkisel, gelişimsel ve bağlamsal. İlişkisel boyutta, mentorlarla deneyimsiz öğretmenler arasındaki ilişkiye; gelişimsel boyutta, belirli amaçlara yönelik olarak mentorların ve deneyimsiz öğretmenlerin kişisel ve profesyonel olarak nasıl geliştiğine; bağlamsal boyutta, mentorluk ortamının kültürel ve durumsal özelliklerine odaklanır. Lai'ye göre (2005) mentorluk, deneyimsiz öğretmenlerin öğretim bağlamında öğrenme fırsatlarını arttırmada önemli bir rol oynamaktadır. Feiman-Nemser (2003) "öğretmenlerin belirli bir bağlamda öğretmeyi öğrenmeleri gerektiğini" belirtir. Bu nedenle bağlamsal koşullara bağlı olan özel mentorluk ortaya çıkmaktadır (Hudson, 2004a, 2004b). Öğretmenler sınıflarının ve bu sinıflarda yaşayan öğrencilerin tüm yönlerinden sorumludurlar. Sağlık veya iş gibi diğer meslek gruplarında ise genellikle bir ekip yaklaşımını veya tamamlanması gereken belirli işleri veya rolleri olan her kişiyi içerir. Eğitim bağlamında ise deneyimsiz öğretmenin mentorun yaptığı tüm görevleri üstlenmesi ve mentorluk ilişkisinin ve sürecinin karmaşık bir şekilde planlanmasını ve organize edilmesini gerekli kılabilir (Aslan ve Öcal, 2012; Hudson, 2004b). Geleneksel olarak daha yaşlı, daha bilgili, daha deneyimli kişiler mentor; daha genç, daha az deneyimli kişiler ise deneyimsiz öğretmenler yani danışanlar(mentiler)dır. Son on yılda, mentorların ve danışanların kim olduğuna dair daha çağdaş bir görüşün ortaya çıtığı görülmektedir (Aslan ve Öcal, 2012; Higgins ve Kram, 2001; Kostovich ve Thurn, 2006). Smith'e (2007) göre, bugünlerde bir mentor, statü ve yaş bakımından eşit olan bir meslektaş olabileceği gibi mentor olan akranlar danışanlardan daha fazla ya da aynı gelişim seviyesinde olabilirler.

Feiman-Nemser (2001) mentorluk kavramını ve tarihsel değişimini incelemiş ve geleneksel mentorluk ile eğitsel mentorluk kavramları arasındaki farklılığı ortaya çıkarmıştır. Ona göre geleneksel mentorlukta amaç, deneyimsiz öğretmenin mesleki yaşamının ilk aşamasında problemleriyle başa çıkmasına ve "hayatta kalmasına" yardımcı olmak ve tüm bunlarla ilgili stresi azaltmaktır. Geleneksel mentorlukta "burada ve şimdi" önemlidir ve duygusal destek ile yardım daha ön plandadır. Eğitici mentorlukta ise yalnızca "hayatta kalmak" ve günlük sorunları çözmek değil, aynı zamanda deneyimsiz öğretmenin kişiliğini, mesleki gelişimini, kariyerini geliştirmek amaçlanmaktadır. Bu nedenle, mentorluk aslında profesyonel çalışmalara düzenli olarak yansiyan, bireyin kişisel ve mesleki gelişim stratejileri geliştirmesine destek veren bir yöntemdir. Richter ve diğerleri (2013), geleneksel mentorluğun yalnızca "hayatta kalmak" veya uzun süreli profesyonel gelişim arayışıyla değil, aynı zamanda öğretim paradigmasıyla da ilgili olduğunu düşünmektedirler. Geleneksel mentorluk, bilgilerin mentor tarafından deneyimsiz kişiye geçirme süreci olarak anlaşılmakta ve öğrencilerin pasif bilgi alıcısı oldukları tek yönlü bir süreç olarak düşünülmektedir. Bu tarz mentorluk modeline aktarım odakl mentorluk denilmektedir.

Hobson, Ashby, Malderez, ve Tomlinson (2009) deneyimsiz öğretmenlerin mesleki gelişimine bağlı olarak mentorluğun farklı amaçları ve bu amaçlara ulaşmak için farklı uygulamaları olduğunu belirtmiştir. 1980'lerden itibaren mentorluk konusu birçok ülkede önem kazanmıştır. Hobson ve diğerleri üç önemli nedenle Amerika Birleşik Devletleri (ABD) ve İngiliz eğitim politikalarında mentorluğa vurgunun arttı̆̆ını söylemektedir: (1) öğretmenlerin mesleğe yeni başladıklarındaki destek ihtiyacını karşılayacak sertifika programlarının artmaya başlaması, (2) mesleğe yeni başlayan öğretmenlerin bazılarının başlangıçta ciddi uyum sorunları yaşamaları, (3) bazı eğitim politikacılarının mentorluk uygulamasını ödüllendirici bir süreç olarak algılamaları. Hobson ve diğerleri (2009) mentorluğa ilişkin yapılmış deneysel çalışmalara ilişkin ayrıntılı bilgi vermektedir. Birçok araştırma mentorluğun mesleğe yeni başlayan öğretmenin yalnızlık hissini azaltma, özgüven geliştirme, mesleki gelişim, kendini değerlendirme ve problem çözme becerilerinin gelişmesinde önemli rolü olduğunu göstermektedir. Araştırmalar ayrıca mentorluğun deneyimsiz öğretmenin kapasitesini artırılmaya, özellikle sınıf yönetimi becerilerini gelişmeye destek olduğunu ve zamanı iyi yönetmelerine yardımcı olduğunu ortaya koymuştur (Aslan ve Öcal, 2012; Flesch, 2005). Bununla birlikte Flesch (2005), birbirine benzer yanları olan ancak farklı olarak adlandırılabilecek mentorluk yaklaşımları olduğunu belirtmektedir. Klinik danışmanlık / gözlem, aynı okulda çalışan mentor ve deneyimsiz öğretmenler tarafından kullanılan yöntemdir. Burada mentor, öğretmenleri dört aşamada gözlemler: gözlem öncesi konferans, sınıf gözlemi, veri analizi ve gözlem sonrası konferans. Bu yöntemde, yeterince eğitim almadıkları ve iş yüklerinden dolayı deneyimsiz öğretmene gereken zamanı ayırmadıklarından dolayı mentorların başarı oranı düşüktür. Stajyerlik mesleğe yeni başlamış ya da eğitimlerinin son yıllarındaki 
öğrencilerin deneyimli bir uygulayıcının yanında deneyim kazanması sürecidir. Bu sistemde mentorlara aday öğretmenlerin yetiştirilmesi sürecine ilişkin sorumluluk verilmektedir. Buradaki temel sorun, ders planını birlikte hazırlayacak vaktin genellikle olmamasıdır. Yeterlik önceden belirlenmiş davranışlar listesine ya da standartlara göre destek verilmesi sürecidir. Son olarak Yansıtma öğretmenlerin kendi öğretim süreçlerini analiz ederek kendi uygulamalarından sorumlu olmalarını sağlayan bir mentorluk uygulamasıdır. Bu yaklaşımı kullanan mentorların öncelikle kendi yansıtma becerilerini geliştirmeleri gerekir. Tüm bunlara ek olarak Flesch (2005) yoğunlaştırılmış mentorluk yaklaşımını da önermektedir. Bu yaklaşımda mentor, öğretmenle birlikte iki hafta süreyle derslere devam etmektedir. 2004'te mesleğe yeni başlamış ve sıkıntı yaşayan 13 gönüllü sınıf öğretmeni yoğunlaştırılmış mentorluk uygulamasına katılmıştır. Yoğunlaştırılmış mentorluk uygulamaları sonucunda öğretmenlerin \%70'inin uygulamalarında anlamlı düzeyde gelişme olduğu saptanmıştır.

Awaya ve diğerleri (2003) çalışmalarında Hawai Üniversitesinde yürütülen Öğretmenlik Yüksek Lisans programı kapsamında öğretmen adaylarının uygulamada geçirdikleri iki yıllık uygulama sürecini anlatmaktadır. Çalışmada mentorluğun kısa sürede biten bir danışmanlık, değerlendirme sürecinden çok uzun süreli bir izleme, paylaşma süreci olduğu ve çok farklı boyutlarının olduğu vurgulanmaktadır. Bahsedilen uygulamanın ilk döneminde aday öğretmenlerin uygulamaya gittikleri okullardaki öğretmenlerden gönüllü olanlarının derslerini izledikleri, ancak herhangi bir mentor-öğrenci ilişkisinin kurulmadığı belirtilmiştir. Uygulamanın ikinci döneminde öğrenciler iki farklı mentor öğretmenle birlikte hazırladıkları ve planladıkları iki üniteyi anlatmışlardır. Üçüncü dönemde öğretmenlik uygulamasına devam edilmiştir. Uygulamanın son döneminde ise öğretmen adaylarına stajyerlik görevleri için ücret ödenmiştir. Bu son dönemde katılımcı okullardaki mentor öğretmenlerle görüşmeler yapılmış ve seçilen dört mentor fakülteyle iş birliği içerisinde öğrencilerin eğitimi sürecinde yer almıştır.

Mentorluk uygulamaları öğretmenlik mesleği için de oldukça önemli ve gereklidir (Aslan ve Öcal, 2012; Sundli, 2007). Öğretmenlik mesleğinde mentorların sorumlulukları diğer iş alanlarına göre farklılaşabilmektedir. Öğretmen eğitiminde mentorluğun önemine vurgu ABD, İngiltere, Finlandiya gibi gelişmiş ülkelerde giderek daha da artmaktadır (Hobson ve diğerleri 2009). Türkiye'de de göreve yeni başlayan öğretmenlerin mesleğe uyumlarını sağlamak için 17/04/2015 tarihli ve 29329 sayılı Resmî Gazete'de yayımlanan Millî Eğitim Bakanlığı Öğretmen Atama ve Yer Değiştirme Yönetmeliği (2015) ile ilk kez mentorluğu da kapsayabilecek bir mesleki uyum çalışması gerçekleştirilmeye başlanmıştır. Bu eğitimde süreç boyunca aday öğretmenlerin sınıf içi, sınıf dışı, okul içi ve okul dışı etkinlikler ile öğretmenlik mesleğine hazır olup mesleki, kişisel ve entelektüel gelişimlerinin desteklenip, eğitim ortamları ve yönetim süreçlerinin işleyişleri hakkında bilgi sahibi olmaları amaçlanmıştır (Yetkiner, 2017).

Öğretmenlik lisans eğitimi sürecinde öğretmenlik uygulaması dersleri mesleğe ilişkin ilk deneyimlerin kazanıldığı dersler olmasına karşın uygulama öğretmenleri bazen bu sorumluluklarının farkında olmaksızın öğretmen adaylarına gerektiği kadar destek vermemekte (Dursun ve Kuzu 2008; Kiraz ve Yıldırım, 2007) ve öğretmen adayları tarafından yapılan uygulamalar günlük etkinlikler olarak görülmektedir. Oysaki dört yıl boyunca alınan teorik derslerin bir yansıması olarak düşünülen uygulama dersleri, öğretmen adayları için çok büyük önem taşımaktadır. Öğretmen adayları bu süreçte kendisinde olması gereken öğretmenlik becerilerini fark ederek eksik olan yönlerini güçlendirmeye çalışacak ve gözlemlediği öğretmen davranışlarını içselleştirecektir. Kozikoğlu ve Senemoğlu'nun (2018) yaptığı araştırmada öğretmen adaylarının öğretimi planlamada ve uygulamada güçlük yaşadıkları ve bu durumun öğretmen adaylarının kendi yetersizliklerinin yanı sıra deneyim eksikliğinden de kaynaklandığı vurgulanmaktadır. Bu yönüyle bakıldığında uygulama öğretmenleri aslında öğretmen adayları için bir "mentor" görevi görmektedirler. Uygulama öğretmenlerine üstlendikleri bu sorumluluğu fark ettirmek ve öğretmen adaylarını nasıl destekleyecekleri konusunda bilgilendirmek gerekmektedir. Ancak ülkemizde şimdiye kadar yapılan çalışmaların çoğu uygulama öğretmenlerinin yeterliklerini belirlemeye yöneliktir (Kiraz, 2003; Zehir Topkaya ve Yalın, 2013) ve uygulama öğretmenlerinin mentorluk becerilerini değerlendiren herhangi bir çalışma bulunmamaktadır. Mentorluk görevini üstlenecek uygulama öğretmenlerinin belirlenmiş ölçütlere göre seçilmesi ve danışanlara (mentilere) 
rehberlik yapabilecek yeterliliğe sahip olup olmadığının belirlenmesi gerekir. Bu çalışma, mentorların bu becerilerinin değerlendirebilmesi açısından alana katkı sağlayabilecek niteliklere sahiptir.

Mentorluk becerilerini belirleme sürecinde öncelikle mentorluk becerilerinin neler olduğu ve mentor olarak görev yapacak kişilerin hangi alanlarda bilgi ve beceri sahibi olmalarının gerektiği belirlenmiştir. Araştırmanın amacı uygulama öğretmenlerinin mentorluk becerilerine sahip olma düzeylerini öğretmen adaylarının bakış açısına göre değerlendirecek bir ölçme aracının geliştirilmesidir. Bu amaçla araştırmada "Mentorluk Becerileri Değerlendirme Aracı (MEBDA)" geliştirilmiştir. Ölçek geliştirme sürecinde öğretmen adaylarının ölçme aracında yer alan ifadelere katılma durumları sorulmuş ve ölçek geliştirme sürecinde bu ifadelerden yararlanılmıştır. Ancak ölçme aracında her bir ifadenin uygulama öğretmeni tarafından gösterilme sıklığı da ölçülebilmektedir.

\section{Yöntem}

Bu bölümde MEBDA'nın geliştirme aşamaları ve çalışma grubunun özellikleri verilmiştir.

\section{Çalışma Grubu}

Araştırma kapsamında çapraz geçerlik çalışması yapıldığı için çalışmanın iki araştırma grubu bulunmaktadır. Birinci araştırma grubundan elde edilen cevaplarla açımlayııı, ikinci araştırma grubundan edinilen cevaplarla da doğrulayıcı analizler gerçekleştirilmiştir.

Araştırma grubunun tespit edilmesi amacıyla öncelikle araştırmanın amacına odaklanılmıştır. Araştırmanın amacı uygulama öğretmenlerinin mentorluk becerilerini ölçmeye yönelik bir ölçme aracı geliştirmektir. Veriler, amaçlı örnekleme yöntemlerinden ölçüt örnekleme yöntemi ile Öğretmenlik Uygulaması I ve II dersini alarak okullarda uygulamalara giden öğretmen adaylarından toplanmıştır. Her iki çalışma grubuna da Ankara il merkezindeki bir devlet üniversitesine bağlı Eğitim Fakültesindeki lisans programlarına devam eden 4. sınıf öğrencileri katılmıştır. Birinci çalışma grubu, Açımlayıcı Faktör Analizinin (AFA) yapıldığ 202 öğretmen adayından oluşmaktadır. İkinci çalışma grubu da Doğrulayıcı Faktör Analizinin (DFA) yapıldığ 232 öğretmen adayıdır. Birinci çalışma grubundaki 202 öğretmen adayının \%24.3'ü erkek ( $\mathrm{n}=$ 49), \%75.7'si ( $\mathrm{n}=153)$ kadındır. Doğrulayıcı Faktör Analizi (DFA) yapılabilmesi için veri toplanan ikinci çalışma grubundaki 232 öğretmen adayının \%70.7'si ( $n=164)$ kadın, \%29.3'ü ( $n=68)$ erkektir.

\section{Veri toplama süreci ve araştırmada izlenilen etik ilkeler}

Araştırma sürecinde öncelikle dördüncü sınıfta öğrencisi olan ve uygulama okulları ile işbirliği yapan farklı lisans programlarının bölüm başkanlarından izinler alınmıştır. Bölüm başkanları tarafından veri toplanmasına onay verilen bölümlerdeki dördüncü sınıf öğrencilerin derslerine girilerek çalışma hakkında bilgilendirme yapılmıştır. Çalışmaya katılmayı kabul eden katılımcılara ölçme araçları ile birlikte gönüllü onam formları dağıtılmıştır. Bu formda katılımcılara araştırma hakkında kısa bir bilgi verilmiş ve gönüllü olan katılımcılarla çalışma yürütülmüştür.

\section{Veri Toplama Aracının Geliştirilmesi}

Uygulama öğretmenlerinin mentorluk becerilerini belirlemeyi amaçlayan ölçme aracında Tezbaşaran (2008) tarafından önerilen ölçek geliştirme basamakları takip edilmiştir.

I. Ölçme aracının amacının ve kapsamının belirlenmesi. Araştırmada ölçme aracı geliştirilirken öncelikle ilgili alan yazın taranarak (Ambrosetti ve Dekkers, 2010; Anderson ve Shannon, 1988; Awaya ve diğerleri, 2003; Crispi ve Cruz, 2009; Feiman-Nemser, 2001; Feiman-Nemser, 2003; Kwan ve Lopez-Real, 2005; MEB, 2017; Stephenson, 2009) bir madde havuzu oluşturulmuştur. Maddeler, MEB (2017) öğretmen yeterlilikleri çalışması, mentor öğretmenlerin yetiştirilmesi ile ilgili ulusal ve uluslararası alan yazın ve Teacher Induction Suppoting The Supporters of Novice Teachers In Europe (TISSNTE) Comenius C21 projesi (Stephenson, 2009) sonuçlarından yararlanılarak mentorluk açısından önemli olduğu düşünülen alanlar olan iletişim, öğrenme ve öğretim süreci, öğretim yöntemleri, sını yönetimi ve geri bildirim verme becerileri gibi alanlar göz önünde bulundurularak hazırlanmıştır. Maddeler yazılırken olgusal ifadeler olmamasına, öz ve sade bir 
biçimde ifade edilmesine, bir madde içinde birden fazla yargı içermemesine ve bir ifade içinde çift olumsuz ifade bulunmamasına dikkat edilmiştir (Tezbaşaran, 2008).

II. Madde havuzunun oluşturulması. Ulaşılan kaynaklardan yola çıkılarak ilk aşamada 66 madde yazılmıştır.

III. Uzman görüşünün alınması. Aracın kapsam geçerliğini sağlamak için uygulama alanında deneyimli ve mentorluğun farklı uygulamaları konusunda uluslararası düzeyde proje deneyimi olan ve öğretmenlik uygulaması derslerine giren üç, öğretmen eğitimi programlarında öğretmenlik uygulaması derslerine giren iki olmak üzere beş alan uzmanından yararlanılmıştır. Alan uzmanlarının hepsi öğretmenlik uygulaması dersini çeşitli lisans programlarında (okul öncesi öğretmenliği, özel eğitim öğretmenliği, sınıf öğretmenliği programlarında) ve öğretmenlik sertifika programlarında yürütmüş, aday öğretmenler ve uygulama öğretmenleri ile çalışmıştır. Alan uzmanları eğitim programları ve öğretim, okul öncesi öğretmenliği ve özel eğitim öğretmenliği alanlarında öğretim elemanı olarak görev yapmaktadırlar.

IV. Deneme formunun oluşturulması. Uzman görüşü doğrultusunda aracın pilot uygulaması için deneme formu hazırlanmıştır. Ölçeğin nasıl doldurulacağı ve amacını kapsayan yönerge yazılmıştır. Mentorluk becerilerini değerlendirmek amacıyla geliştirilen bu araçtaki maddeleri yanıtlarken öğretmen adaylarının uygulamaya gittikleri kurumda görev yapan uygulama öğretmenlerini dikkate almaları ve ihtiyaç duydukları desteği düşünmeleri istenmiştir. Maddelerin anlaşılırlığı, açılığı konusunda geri bildirim almak amacıyla 49 kişilik bir grup lisans öğrencisine ön deneme uygulaması yapılmıştır. Maddelerin anlaşılır olduğu saptanmıştır. Maddeler 5’li Likert tipinde derecelendirilmiştir. Ölçme aracında olumsuz ifade taşıyan madde bulunmamaktadır.

V. Ön uygulamanın yapılması. Deneme formu uygulamasından sonra değerlendirmeler sonunda 5'li Likert tipi, kapalı uçlu 66 maddeden oluşan aracın ilk hali oluşturulmuştur. Araçta, öğretmen adaylarının, uygulama öğretmenlerinin mentorluk becerilerine sahip olup olmadıklarını belirleyebilmeleri için her bir maddeyi 1-5 puan arasında değerlendirerek işaretlemeleri istenmiştir (1: "Kesinlikle Katılmıyorum", 2: "Katılmıyorum", 3: “Kararsızım", 4: “Katılıyorum", 5: "Kesinlikle Katılıyorum"). Toplam puanın yüksekliği öğretmenin mentorluk becerilerinin yüksek olduğunu göstermektedir. 202 öğretmen adayından oluşan birinci araştırma grubunun verileriyle AFA, 232 öğretmen adayından oluşan ikinci araştırma grubunun verileriyle de DFA gerçekleştirilerek ölçeğin yapı geçerliğine ilişkin kanıtlar elde edilmiştir.

\section{Verilerin Analizi}

MEBDA'nın yapı geçerliğini belirleyebilmek ve faktör yapısını ortaya çıkarmak amacıyla yapılan AFA sonucunda elde edilen faktör yapısının doğruluğunu test etmek amacıyla da DFA yapılmıştır. Bu iki faktör analizi tekniğinin aynı çalışmada kullanılmasının nedeni AFA aracılığıyla ölçeğin yapısını keşfetmek ve açığa çıkarmak, DFA analizi ile elde edilen bu faktör yapısının doğrulanıp doğrulanmadığını kontrol etmektir (Büyüköztürk, Akgün, Özkahveci ve Demirel, 2004). Analizler öncesinde veri setlerinin büyüklük, normallik, uç değer ve çoklu bağlantı olmak varsayımları olmak üzere analizlere uygunluğu incelenmiştir.

AFA'ya başlamadan önce The Kaiser-Meyer-Olkin Measure of Sampling Adequacy (KMO) ve Barlett testi hesaplanmıştır. KMO, bir bağımlı ve tek bir bağımsız değişken arasındaki ilişkinin gücünü, diğer tüm bağımsız değişkenlerin etkisi sabit tutulduğunda ölçen bir değerdir. Bu değerin 0.50 'den düşük olması halinde faktör analizine devam edilemeyeceği belirtilir. Öğretmen adaylarından elde edilen cevaplar doğrultusunda hesaplanan KMO değerinin .953 olduğu görülmüştür. Bu değer, örneklem sayısının ve maddeler arasındaki faktörleşmenin "mükemmel" olduğunu göstermektedir (Tavşancıl, 2010). Ayrıca "Korelasyon matrisindeki korelasyonlar sıfıra eşittir (değişkenler arası ilişki yoktur)." Yokluk (Null) hipotezini test etmek için kullanılan Bartlett testi anlamlı bulunmuş, dolayısıyla değişkenler arası ilişki olduğu ve bu ilişkinin istatistiksel anlamda “önemli” olduğu belirlenmiştir. 


\section{Bulgular ve Yorumlar}

$\mathrm{Bu}$ bölümde öncelikle birinci araştırma grubundan elde edilen MEBDA'nın AFA bulguları; ikinci araştırma grubundan elde edilen MEBDA'nın DFA bulguları ve güvenirlik bulguları verilmiştir.

Geçerlik çalışmaları kapsamında kapsam geçerliği için ölçme aracındaki maddelere ilişkin uzman görüşleri alınmış, yapı geçerliği için açımlayıcı ve doğrulayıcı faktör analizi çalışmaları yapılmış ve madde toplam korelasyonlarına bakılmıştır.

\section{Açımlayıcı Faktör Analizi (AFA) Bulguları}

Mentorluk Becerileri Değerlendirme Aracı'nın (MEBDA) yapısını belirlemek amacıyla öncelikle birinci araştırma grubundan elde edilen verilerle AFA yapılmıştır. 202 öğretmen adayından alınan görüşler doğrultusunda öncelikle KMO ve Barlett testleri hesaplanmıştır. KMO değerinin 0,953 olduğu ve Barlett testinin anlamlı olduğu $(p<0,05)$ belirlenmiştir. Hesaplanan değerler veri setinin faktör analizi için "mükemmel" düzeyde uygun olduğunu göstermiş (Tavşancıl, 2010) ve analize devam edilmiştir.

AFA sonucunda her bir maddenin ayırt ediciliğine (madde-toplam test korelasyonları) bakılmıştır. Madde-toplam puan korelasyonu, test maddelerinden alınan puanlar ile testin toplam puanı arasındaki ilişkiyi açıklamaktadır (Tezbaşaran, 2008). Madde-toplam korelasyonunun pozitif ve yüksek olması bir ölçme aracındaki her bir maddenin benzer davranışları örneklediğini ve testin iç tutarlılığının yüksek olduğunu gösterir. Likert tipi derecelendirme araçlarının kullanıldığı bir testte madde-toplam puan korelasyonu Pearson korelasyon katsayısı ile hesaplanır. Genel olarak madde-toplam korelasyonu .45 ve daha yüksek olan maddelerin iyi derecede ayırt ettiği belirtilmektedir (Büyüköztürk, 2008, s. 118).

AFA sonucunda maddelerin faktör yük değerleri incelenmiştir. Faktör yük değerleri için kesme noktası .45 olarak belirlenmiş ve .45 değerinin altında olan 25 madde araçtan çıarılmıştır. Bu nedenle aracın iyi derecede ayırt edici maddelerden oluştuğu söylenebilir. 66 maddelik madde havuzundan faktör yük değerleri .45 ve altında olan maddeler olan 1., 6., 7., 12., 16., 17., 20., 21., 27., 29., 30., 34., 36., 37., 41., 43., 44., 45., 46., 48., 50., 51., 54., 60., 62. maddeler araçtan çıkarılmıştır. Ayrıca maddeler binişiklik açısından da incelenmiş ve araçta yer alan maddeler arasında binişikliğin olmadığı belirlenmiştir. Bu doğrultuda yeniden numaralandırılan 41 maddelik araçtaki maddelerin madde-toplam puan korelasyonu, temel bileşenler analizi birinci, ikinci, üçüncü faktör yükleri Tablo 1'de verilmiştir.

Tablo I

Mentorluk Becerileri Değerlendirme Aracının Faktör Analizi (Döndürülmüş Temel Bileşenler Analizi) Sonuçları

\begin{tabular}{|c|c|c|c|c|}
\hline \multirow[b]{2}{*}{ Madde No } & \multicolumn{3}{|c|}{ Döndürülmüs Faktörler İçin Yük Değerleri } & \multirow{2}{*}{$\begin{array}{l}\text { Madde Toplam Puan } \\
\text { Korelasyonu }\end{array}$} \\
\hline & Faktör-1 & Faktör-2 & Faktör-3 & \\
\hline 1 & & 0,687 & & 0,789 \\
\hline 2 & & 0,721 & & 0,708 \\
\hline 3 & & 0,770 & & 0,782 \\
\hline 4 & & 0,746 & & 0,780 \\
\hline 5 & & 0,577 & & 0,581 \\
\hline 6 & & 0,665 & & 0,761 \\
\hline 7 & & 0,581 & & 0,764 \\
\hline 8 & & 0,624 & & 0,827 \\
\hline 9 & & 0,667 & & 0,759 \\
\hline 10 & & 0,572 & & 0,557 \\
\hline 11 & & 0,549 & & 0,702 \\
\hline 12 & 0,702 & & & 0,800 \\
\hline 13 & 0,603 & & & 0,636 \\
\hline 14 & & & 0,574 & 0,508 \\
\hline 15 & & 0,629 & & 0,746 \\
\hline 16 & 0,663 & & & 0,777 \\
\hline 17 & 0,723 & & & 0,732 \\
\hline 18 & 0,650 & & & 0,806 \\
\hline 19 & & & 0,558 & 0,502 \\
\hline 20 & & & 0,491 & 0,689 \\
\hline 21 & & & 0,614 & 0,604 \\
\hline
\end{tabular}




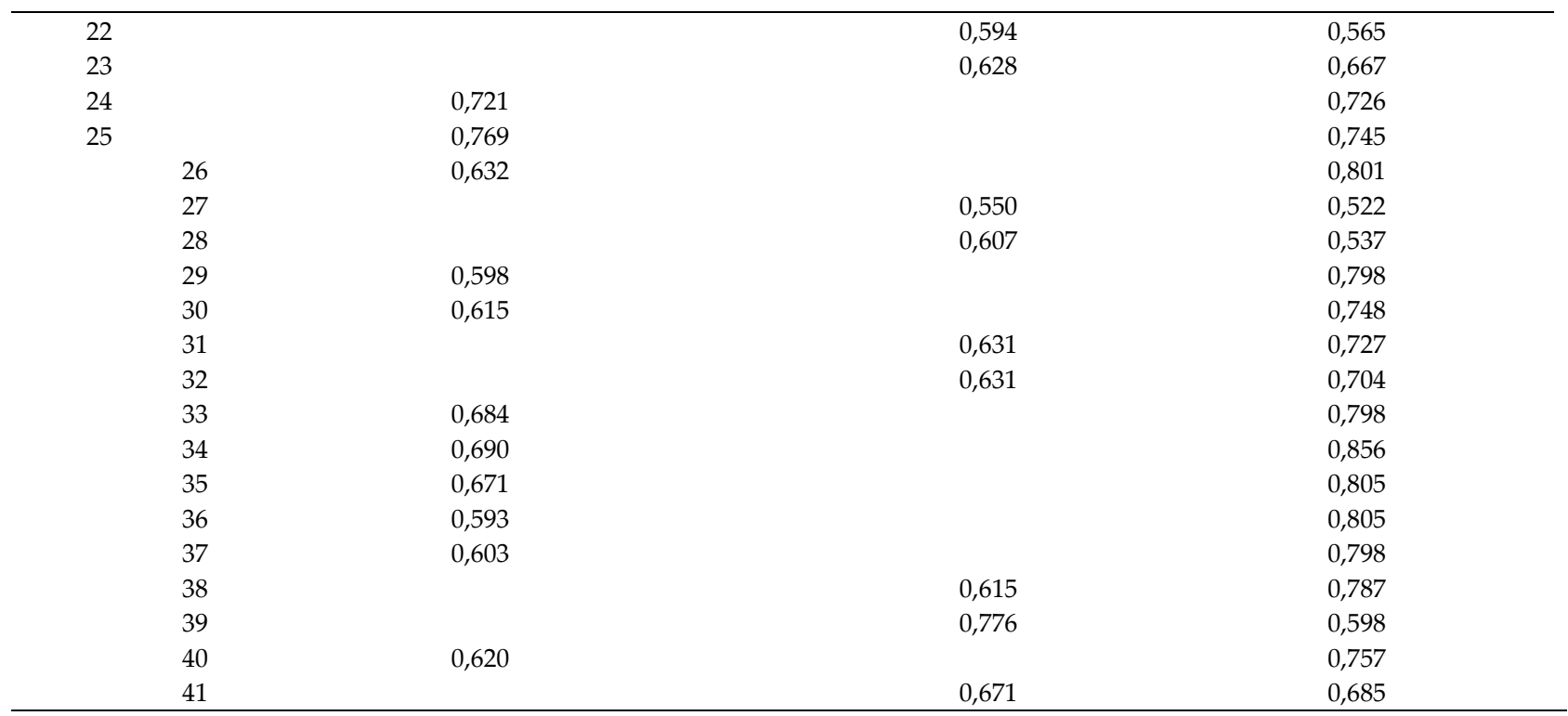

Açıklanan Varyans: Toplam: \%60; Faktör-1: \%23, Faktör-2: \%18, Faktör-3: \%18

AFA sonucunda, ölçme aracının üç boyuttan oluştuğu saptanmıştır. Bu üç alt boyut Öğrenme Öğretme Süreci, Illetişim Süreci ve Mesleki Gelişim Süreci olarak adlandırılmıştır. Araçta Öğrenme Öğretme Süreci boyutunda 16 madde, İletişim Süreci boyutunda 12 madde, Mesleki Gelişim boyutunda 13 madde olmak üzere toplam 41 madde yer almaktadır (Tablo 2).

Tablo 1'de yer alan bilgiler incelendiğinde ölçme aracının birinci boyutunda yer alan 16 maddenin faktör yük değerlerinin 0,593 ile 0,769 arasında değişiklik gösterdiği görülmektedir. Başka bir anlatımla ölçme aracında yer alan maddeler ait oldukları boyutu "iyi düzeyde" açıklamaktadır (Tabachnick ve Fidell, 2015). Birinci boyutundaki maddeler varyansın \%23'üne açılık getirmektedir. Aracın ikinci boyutunda bulunan 12 maddenin faktör yük değerlerinin 0,45'ten yüksek olduğu; 0,549 ile 0,770 arasında değişiklik gösterdiği saptanmıştır. İkinci boyuttaki maddeler varyansın \%18'ine açıklık getirmektedir. Üçüncü boyutta yer alan 13 maddenin de faktör yük değerlerinin 0,45'ten yüksek olduğu; 0,491 ile 0,776 arasında değişiklik gösterdiği saptanmıştır. Üçüncü boyuttaki maddeler varyansın \%18'ine açıklık getirmektedir. Ölçme aracında yer alan 41 maddenin toplam varyansın \%60'ını açıkladığı belirlenmiştir. Çok faktörlü desenlerde açıklanan varyansın \%40 ile \%60 arasında olması, yeterli kabul edilebilmektedir (Çokluk, Şekercioğlu ve Büyüköztürk, 2014). Aracın açıladığı varyans miktarı ve maddelerin faktör yük değerleri incelendiğinde geliştirilen ölçme aracının yapı geçerliğinin "iyi düzeyde" olduğu görülmektedir.

Tablo II

Mentorluk Becerileri Değerlendirme Aracında Yer Alan Boyutlar ve Maddeler

\begin{tabular}{lcl}
\hline Mentorluk Becerileri & Madde Sayıs & \multicolumn{1}{c}{ Maddeler } \\
\hline 1.Boyut: Ö̆ğrenme Öğretme Süreci & 16 & $12,13,16,17,18,24,25,26,29,30,33,34,35,36,37,40$ \\
2. Boyut: İletişim Süreci & 12 & $1,2,3,4,5,6,7,8,9,10,11,15$ \\
3. Boyut: Mesleki Gelişim Süreci & 13 & $14,19,20,21,22,23,27,28,31,32,38,39,41$ \\
\hline
\end{tabular}

Öğrenme Öğretme Süreci alt boyutunda, mentorun ders öncesi öğrenme etkinliklerini planlama, ders materyali hazırlama, öğretim yöntemini seçme ve uygulama konularında öğretmen adaylarını destekleme, yenilikleri ve sorunları öğretmen adaylarıyla paylaşma, öğrencilerdeki motivasyonu artırma ve beklenmeyen olaylarla karşılaşıldığında nasıl davranılması gerektiği konusunda yol gösterme ve uygulamalarla ilgili geri bildirim verme gibi maddelere yer verilmiştir.

Örnek madde: Uygulama öğretmenim ders öncesinde öğrenme etkinliklerini planlamam konusunda beni destekler. 
İletişim Süreci alt boyutu, mentorun öğretmen adayıyla empati kurması, gereksinimlerinin farkında olması, yapıcı eleştirilerde bulunması ve sınıf içerisinde iyi bir öğrenme ortamı yaratması gibi iletişim becerilerini kapsayan maddeleri içermektedir.

Örnek madde: Uygulama öğretmenimin bana yönelik eleştirilerinin yapıcı olduğunu düşünüyorum.

Mesleki Gelişim Süreci alt boyutunda da, öğretmen adaylarının kendini okulun bir parçası olarak hissetmesi, uygulamalardan doyum sağlaması, okul kurallarının gerekliliğini algılaması ve uygulamada kazanılan becerilerin kendilerini mesleğe hazırladığını ve öğretim stratejileri, hedef belirleme vb. konularda bilgilerinin arttığını düşünmesine ilişkin maddelere yer verilmiştir.

Örnek madde: Öğretmen olmanın ne anlama geldiğini anladım.

\section{Doğrulayıcı Faktör Analizi (DFA) Bulguları}

AFA sonucuna göre 41 maddeye düşen ölçme aracı, 232 öğretmen adayına daha uygulanarak DFA yapılmıştır. DFA, klasik faktör analizi çalışmalarından sonra uygulanan bir analizdir (Bollen ve Long, 1993). Burada araştırmacılar Açımlayıcı Faktör Analizi çalışmasıyla belirlemiş oldukları faktör yapılarına DFA uygulayarak veri setinin ortaya koyduğu faktör yapıları test edilmektedir (Şimşek, 2007, s.4). Şimşek (2007) sağlam bir teorik temele sahip olmayan çalışmaların AFA sonuçları çok iyi olsa da DFA sonuçlarının kötü olabildiğini belirtmektedir.

MEBDA yapı geçerliliği kapsamında model uyumunun doğruluğunu test etmek için yapılan DFA sonucunda modelin gözlenen değişkenleri açıklama oranlarına ilişkin $t$ değeri Şekil 1'de gösterilmiştir. Üç boyutlu model için gizil değişkenlerin gözlenen değişkenleri açıklama durumlarına ilişkin $t$ değerleri oklar üzerinde gösterilmiştir. Çokluk ve diğerleri (2014) t değeri 1.96'yı aşarsa 0.05 düzeyinde, 2.56 'yı aşarsa 0.01 düzeyinde anlamlı olduğunu ve anlamlı olmayan değerlerin analiz dışı bırakılması gerektiğini belirtmektedir. Şekil l'de görüldüğü üç boyutlu model için gizil değişkenlerin gözlenen değişkenleri açılama durumlarına ilişkin $t$ değerleri 7.53- 16.30 arasında değişmektedir. Araç maddelerinin $t$ değerleri 0.01 düzeyinde anlamlı olduğu için DFA sonucunda analiz dışı bırakılan bir madde olmamıştır. 


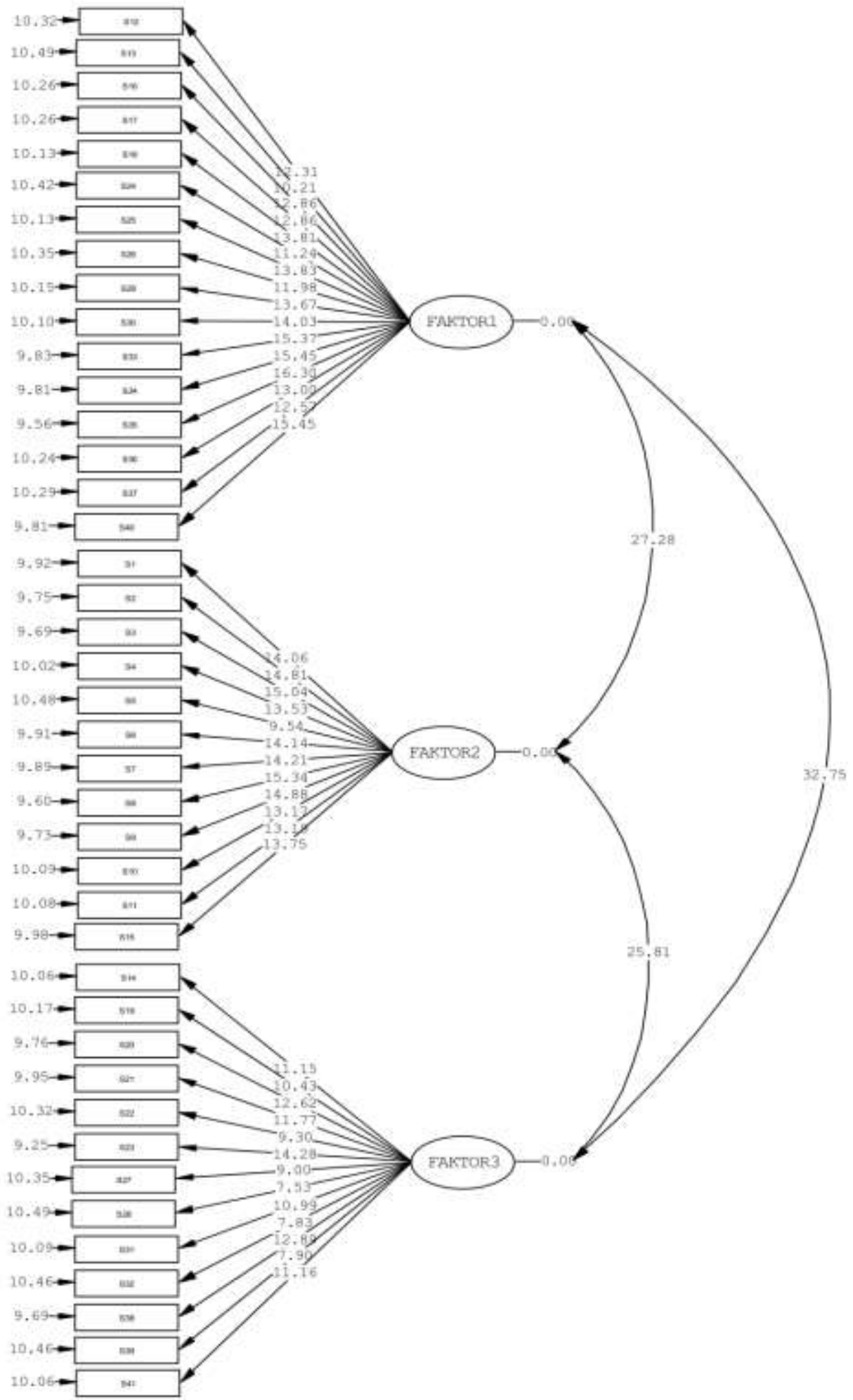

Chi-Square $=2328.07$, df $=776$, $P$-value $=0.00000$, RMSEA $=0.093$

Şekil 1. MEBDA doğrulayıcı faktör analizi t-değerleri 
Standardize edilmiş değerler Şekil 2' de verilmiştir.

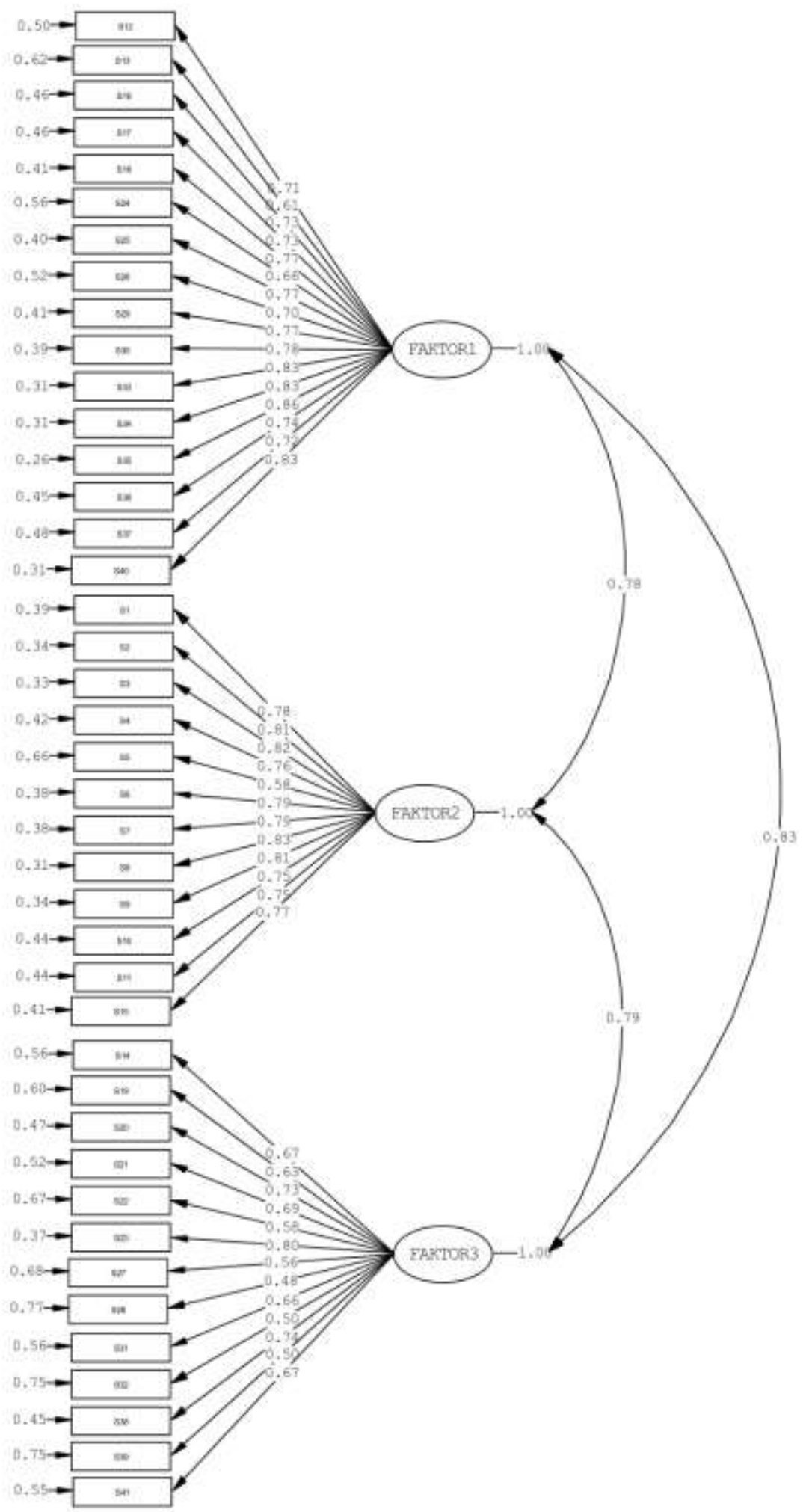

Chi-Square $=2328.07, d f=776, p$-value $=0.00000$, FMSEA $=0.093$ 
Şekil 2'de görüldüğü gibi maddelerin hata varyansları 0.90 'dan küçüktür ve $0.48-0.86$ arasında değişmektedir. Maddelerin faktörlerle ilişkilerine bakılınca birinci faktör (öğrenme öğretme süreci) ve maddeleri arasında 0.61-0.86 arasında değişen bir ilişki, ikinci faktör (iletişim süreci) ve maddeleri arasında 0.58-0.83 arasında değişen bir ilişki, üçüncü faktör (mesleki gelişim süreci) ve maddeleri arasında 0.48- 0.80 arasında değişen bir ilişki vardır. Birinci faktör ile ikinci faktör arasındaki ilişki 0.78 , birinci faktör ile üçüncü faktör arasındaki ilişki 0.83, ikinci faktör ile üçüncü faktör arasındaki ilişki 0.79 bulunmuştur. İstatistiksel analizler sonucunda $\chi^{2}=2328.07, \mathrm{sd}=776, \mathrm{p}=0.00, \mathrm{RMSEA}=0.093$ olarak bulunmuştur. $\chi^{2}$. tek başına değerlendirilmemekte, serbestlik derecesi ile orantılandırılarak ( $\left.\chi^{2} / \mathrm{sd}\right)$ değerlendirmeye alınmaktadır (Çokluk ve diğerleri, 2014). Bu oranın 5'in altında olması orta düzeyde (kabul edilebilir) uyum, 3'ün altında olması mükemmel uyum olduğunu gösterir (Çokluk ve diğerleri, 2014). MEBDA ölçeği için bu oran 3'tür ve "iyi uyum" olduğunu göstermektedir.

Tablo III

Mentorluk Becerileri Değerlendirme Aracı (MEBDA) Uyum İyiliği Değerleri

\begin{tabular}{ll}
\hline Uyum değerleri & Kabul için kesme noktaları \\
\hline$\chi 2 .=2328.07$ & $<2$ mükemmel uyum, $\leq 3$ iyi uyum \\
$\chi 2 . /$ sd $=3$ & $\leq 0.05$ iyi uyum \\
\hline RMSEA $=0.093$ & $\leq 0.08$ kabul edilebilir uyum \\
\hline RMR $=0.082$ & $\leq 0.05$ mükemmel uyum \\
SRMR $=0.066$ & $\leq 0.08$ iyi uyum \\
\hline CFI $=0.97$ & \\
NNFI $=0.97$ & $\geq 0.90$ iyi uyum \\
NFI $=0.95$ & $\geq 0.95$ mükemmel uyum \\
IFI $=0.97$ & \\
RFI $=0.95$ & \\
\hline
\end{tabular}

RMSEA değerinin .05'ten küçük olması mükemmel uyumu, .08'den küçük olması iyi uyumu göstermektedir (Çokluk ve diğerleri, 2014). RMSEA değerlerine göre modelin uyumuna bakıldığında kabul edilebilir düzeyde ancak zayıf uyum gösterdiği görülmektedir. Bu durumda diğer değerlere bakılması önerilmektedir (Çokluk ve diğerleri, 2014). Model uyumunu değerlendirilmesinde CFI ve NNFI'nın .95'in üzerinde olması mükemmel uyuma, .90'ın üzerinde olması iyi uyuma karşılık gelmektedir (Çokluk ve diğerleri, 2014; Hu ve Bentler, 1999). Aracın CFI ve NNFI değerleri 97 olduğundan modelin iyi uyum gösterdiği söylenebilir. Ayrıca, maddelerin boyutlarla olan ilişkilerini gösteren standartlaştırılmış yol katsayısı değerleri ve $t$ değerleri de modelin uyumunu desteklemektedir.

MEBDA'nın güvenirlik çalışması için ölçeğin Cronbach Alfa katsayısı hesaplanarak iç tutarlılık katsayısı hesaplanmıştır. Cronbach (1951) tarafından geliştirilen alfa katsayısı yöntemi, maddeler doğru-yanlış olacak şekilde puanlanmadığında, 1-3, 1-4, 1-5 gibi puanlandığında, kullanılması uygun olan bir iç tutarlılık tahmin yöntemidir (Akt. Öncü, 1994). Aracın bütününe ilişkin Cronbach Alfa katsayısı .97 olarak bulunmuştur. Ö̆grenme Öğretme Sürecine ilişkin alt boyutun Cronbach Alfa katsayısı .95, İletişim Sürecine ilişkin alt boyutun Cronbach Alfa katsayısı .94, Mesleki Gelişim Süreci alt boyutunun Cronbach Alfa katsayısı .89 olarak bulunmuştur. Literatürde .80'in üzerindeki değerler iyi olarak değerlendirilmektedir (Alpar, 1998). Buna göre MEBDA'nın güvenirlik katsayısının oldukça yüksek olduğu söylenebilir.

Yapılan analizlere ilişkin tüm sonuçlar, MEBDA'nın uygulama öğretmenlerinin mentorluk becerilerini değerlendirmede geçerli ve güvenilir bir araç olarak kullanılabileceğini göstermektedir.

\section{Sonuç ve Tartışma}

Her meslekte olduğu gibi öğretmenler de mesleklerinin ilk yıllarında güçlükler yaşamakta, destek ve yardıma gereksinim duymaktadırlar. Mesleğin ilk yıllarında yaşanılan zorluklar kişiden kişiye farklılık gösterse de genelde deneyim eksikliğine bağlı olarak öğretmenler, öğretme sürecinde zorluklar 
yaşamaktadırlar (Kozikoğlu ve Senemoğlu, 2018). Hizmet öncesi eğitim ne kadar nitelikli olursa olsun, mesleğe ilişkin beceriler uygulama ve staj süreci içinde edinilmektedir.

Ülkemizde öğretmen adayları son yıllarında belirli sürelerde uygulama için okullara gitmekte, ancak uygulama öğretmenleri mentor eğitiminden geçmedikleri ve kendisinden beklenen sorumlulukların farkında olmadıkları için öğretmen adaylarına yeterli desteği verememektedirler. Yeni göreve başlayacak öğretmenlerin hizmet öncesi uygulamalarında ve hizmet içinde meslek yaşamlarının ilk yıllarını en az sorunla atlatmaları nitelikli bir eğitim ve hazırlıkla olasıdır. Bu hazırlık aşamalarını mentor desteği ile mesleğin gerektirdiği becerileri kazanmış olarak tamamlamaları, onların ilerleyen yıllarda başarılı öğretmenler olmalarını sağlayacaktır. Mentorluğun eğitim alanında kullanılması yeni göreve başlayan öğretmenler ve okul müdürlerine mesleki ve kişisel yardım sağlanması açısından önemlidir. Süreç Amerika, İngiltere Singapur ve pek çok Avrupa ülkesinde başarıyla uygulanmaktadır (Yirci ve Kocabaş, 2011). Araştırmalar, mesleğe yeni başlayan öğretmenlerin yalnızlık hislerinin azalmasında, özgüven geliştirmelerinde, mesleki gelişimlerinde, sınıf yönetimi ve zamanı iyi yönetme becerilerinin gelişiminde, kendini değerlendirme ve problem çözme becerilerin gelişiminde mentorluğun olumlu etkisi olduğunu ortaya koymaktadır (Awaya ve diğerleri, 2003; Hobson ve diğerleri, 2009).

Mentorluk sürecinin doğru işlemesi için mentor ve danışanların (mentilerin) sorumluluklarını tam olarak algılamaları ve uyumlu olmaları gerekmektedir. Süreç içinde mentorluk yapacak öğretmenlerin bir program dahilinde yetiştirilmeleri ve mentorluk becerilerinin değerlendirilmesi gerekmektedir. Bu çalışmada geliştirilen MEBDA öğrenme-öğretme, iletişim ve mesleki gelişim süreci alt boyutları ile mentorluk becerilerinin değerlendirilmesinde geçerli ve güvenilir bir araç olarak kullanılacak özelliklere sahiptir.

MEBDA'daki maddeler mentorlukla ilgili alan yazında belirtilen beceriler, uygulama öğretmenlerinin aday öğretmenleri yönlendirme sürecinde sahip olmaları beklenen yeterlikler, MEB öğretmenlik genel yeterlikleri ve TISSNTE projesi bulguları (Stephenson, 2009) doğrultusunda belirlenmiştir. Ölçme aracındaki maddeler mentorluk açısından önemli olduğu düşünülen alanlar olan iletişim, öğrenme ve öğretim süreci, öğretim yöntemleri, sınıf yönetimi ve geri bildirim verme becerileri göz önünde bulundurularak hazırlanmıştır. 66 maddeden oluşan araç AFA sonucunda madde-toplam korelasyonu .45 ve altında olan maddeler çıkarılarak 41 maddeye düşürülmüş ve ölçme aracının üç boyuttan oluştuğu belirlenmiştir. Alt boyutlardaki maddeler dikkate alınarak MEBDA'nın birinci boyutu öğrenme-öğretme süreci, ikinci boyutu iletişim süreci, üçüncü boyutu mesleki gelişim süreci olarak adlandırılmıştır. Yapılan DFA sonucunda araç maddelerinin $t$ değerleri 0.01 düzeyinde anlamlı olduğu için analiz dışı bırakılan bir madde olmamıştır. DFA sonucundaki $\chi^{2}$. değerinin serbestlik derecesine uyumu modelin iyi uyum gösterdiğini ortaya koymuştur.

Ölçme aracının güvenirliğini ölçebilmek için Cronbach Alpha iç tutarlılık değerleri hesaplanmış ve bu değer öğrenme-öğretme süreci alt boyutu için .96, iletişim süreci alt boyutu için .95, mesleki gelişim süreci alt boyutu için .92 olarak bulunmuştur. Araç, bu özellikleri ile uygulama öğretmenlerinin mentorluk becerilerinin değerlendirilmesinde kullanılabileceği gibi, mentor yetiştirme programlarının hazırlanmasında ve uygulanan programın değerlendirilmesinde de yararlanılabilir. Ayrıca mentor eğitim materyallerinin oluşturulmasında ve etkinliklerin planlanmasında MEBDA alt boyutları ve içeriği ile önemli katkılar sağlayabilir.

\section{Yazar(lar)ın Beyanı}

Araştırmacıların katkı oranı beyanı: Araştırmanın tasarlanması ve ölçek maddelerinin yazılması sürecinde tüm araştırmacılar birlikte çalışmışlardır. Gerekli izinlerin alınmasında Prof. Dr. Gönül Akçamete, literatür bölümünün hazırlanmasında Prof. Dr. Çağlayan Dinçer, yöntem ve analiz bölümünün hazırlanmasında Doç. Dr. Berna Aslan aktif görev yapmıştır. Makalenin sonuç ve tartışma bölümü tüm araştırmacıların katkısı ile tamamlanmıştır. Ayrıca makalenin tamamı tüm araştırmacılar tarafından okunarak gerekli ekleme ve düzenlemeler yapılmıştır.

Çatışma beyanı: Araştırmada, yazarların kendi içinde ve diğer kişi/kurum/kuruşlarla herhangi bir çıkar çatışması söz konusu değildir.

Destek ve teşekkür: Herhangi bir kurum kuruluştan destek alınmamıştır. Araştırmamızın yöntem bölümüne verdiği desteklerden dolayı sayın Doç. Dr. Deniz Gülleroğlu'na çok teşekkür ederiz. 


\section{Kaynaklar}

Alpar, R. (1998). İstatistik ve spor bilimleri. Ankara: Bağırgan Yayınevi.

Aslan, B. ve Öcal, S. (2012). A case study on mentoring in a teacher development program. Journal of Education and Future, 1(2), 31-48.

Ambrosetti, A. ve Dekkers, J. (2010). The interconnectedness of the roles of mentors and mentees in pre-service Teacher Education Mentoring Relationships. Australian Journal of Teacher Education, 35(6), 42-55.

Anderson, E. M. ve Shannon, A.L. (1988). Towards a conceptialization of mentoring. Journal of Teacher Education, 39(1), 38-42.

Awaya, A., McEwan, H., Heyler, D., Linsky, S., Lum, D. ve Wakukawa, P. (2003). Mentoring as a journey. Teaching and Teacher Education, 19 (1), 45-56.

Büyüköztürk, Ş. (2008). Sosyal bilimler için veri analizi el kitabı. Ankara: PegemA Yayıncılık.

Büyüköztürk, Ş. , Akgün, Ö.E., Özkahveci, Ö. and Demirel, F. (2004). Güdülenme ve öğrenme stratejileri ölçeğinin Türkçe formunun geçerlik ve güvenirlik çalışması. Kuram ve Uygulamada Eğitim Bilimleri, 4(2), 207-239.

Bollen, K. A. ve Long, J. S. (1993). Testing structural equation models. London: Sage Publications.

Cain, T. (2009). Mentoring trainee teachers: how can mentors use research? Mentoring $\mathcal{E}$ Tutoring: Partnership in Learning, 17(1), 53-66.

Crispi, G. ve Cruz, I. (2009). Mentorig college students: A critical review of the literature between 1990 and 2007. Research in Higher Education, 50(6), 525-622.

Çokluk, Ö., Şekercioğlu, G. ve Büyüköztürk, Ş. (2014). Sosyal bilimler için çok değişkenli istatistik SPSS ve Lisrel Uygulamaları. Ankara: Pegem Akademi.

Daresh, J. C. (2003). Teachers Mentoring Teachers. A practical approach to helping new and experienced staff. Corwin Press, Inc.

Dursun, Ö.Ö. ve Kuzu, A. (2008). Öğretmenlik uygulaması dersinde yaşanan sorunlara yönelik öğretmen adayı ve öğretim elemanı görüşleri. Selçuk Üniversitesi Ahmet Keleşoğlu Eğitim Fakültesi Dergisi, Sayı 25, 159-178.

Fairbanks, C. M., Freedman, D. ve Kahn, C. (2000). The role of effective mentors in learning to teach. Journal of Teacher Education, 51(2), 102 -112.

Feiman-Nemser, S. (2001). Helping novices learn to teach: Lessons from an exemplary support teacher. Journal of Teacher Education, 52(1), 17- 30.

Feiman-Nemser, S. (2003). What new teachers need to learn. Educational Leadership, 60(8), 25-30.

Flesch, G. (2005). Mentoring the non-coping teacher: A preliminary study. Journal of Education for Teaching, 11(2), 69-86.

Fletcher, S. (2000). Mentoring in schools: A handbook of good practice. London: Kogan Page.

Higgins, M. C. ve Kram, K. E. (2001). Reconceptualizing mentoring at work: A developmental network perspective. The Academy of Management Review, 26(2), 264-288.

Hobson, A. J., Ashby, P., Malderez, A. ve Tomlinson, P. D. (2009). Mentoring beginning teachers: What we know and what we don't. Teaching and Teacher Education, 25 (1), 207-216.

Hu, L. and Bentler, P. M. (1999). Cutoff criteria for fit indexes in covariance structure analysis: Conventional criteria versus new alternatives. Structural Equation Modeling: A Multidisciplinary Journal, 6(1), 1-55. 
Hudson, P. (2004a). Specific mentoring: A theory and model for developing primary science teaching practices. European Journal of Teacher Education, 27(2), 139-146, doi: 10.1080/0261976042000223015

Hudson, P. (2004b). Toward identifying pedagogical knowledge for mentoring in primary science teaching. Journal of Science Education and Technology, 13(2), 215-225. doi:10.1023/B:JOST.0000031260.27725.da

Kwan, T. ve Lopez-Real, F. (2005). Mentors' perceptions of their roles in mentoring student teachers. AsiaPacific Journal of Teacher Education, 33(3), 275-287.

Kiraz, E. (2003). Uygulama öğretmeni yeterlilik ölçeği. Türk Eğitim Bilimleri Dergisi, 1(4), 387- 398.

Kiraz, E. ve Yıldırım, S. (2007). Enthusiasm vs. experience in mentoring: A comparison of Turkish novice and experienced teachers in fulfilling supervisory roles. Asia Pacific Education Review, 8(2), 250-261.

Kostovich, C. T. ve Thurn and K. E. (2006). Reconceptualizing mentoring at work: A developmental network perspective. Academy of Managment Rewiew, 26(21), 264-288.

Kozikoğlu, İ. ve Senemoğlu, N. (2018). Mesleğe yeni başlayan öğretmenlerin karşılaştıkları güçlükler: Nitel bir çözümleme. Eğitimde Nitel Araştırmalar Dergisi, 6(3), 341-371. doi:10.14689/issn.2148-2624.1.6c3s16m

Lai, E. (2005). Mentoring for in-service teachers in a distance teacher education programme: Views of mentors, mentees and university teachers. Paper presented at the Australian Association for Research in Education International Education Research Conference. November, Parramatta, NSW: University of Western Sydney. Erişim Adresi: http://www.aare.edu.au/05pap/lai05100.pdf.

MEB, (1998). Öğretmen adaylarının milli eğitim bakanlığına bağlı eğitim öğretim kurumlarında yapacakları öğretmenlik uygulamasına ilişkin yönerge. Tebliğler Dergisi, Ekim, 1998/2493. Erişim adresi: http://mevzuat.meb.gov.tr/dosyalar/263.pdf

MEB (2017). Öğretmenlik Mesleği Genel Yeterlikleri. MEB Öğretmen Yetiştirme ve Eğitimi Genel Müdürlüğü: Ankara. Erişim adresi:

https://oygm.meb.gov.tr/meb_iys_dosyalar/2017_12/11115355_YYRETMENLYK_MESLEYY_GENEL_YE TERLYKLERY.pdf

Millî Eğitim Bakanlığı Öğretmen Atama ve Yer Değiştirme Yönetmeliği (2015, 17 Nisan). Resmi Gazete (Sayı: 29329). Erişim adresi: https://www.resmigazete.gov.tr/eskiler/2015/04/20150417-4.htm

Monkeviciene, O. ve Autukeviciene, B. (2015). The competences of educative mentor, fostering change in the early childhood education, Procedia-Social and Behavioral Sciences, 197, 885-891.

Öncü H. (1994). Eğitimde ölçme ve değerlendirme. Ankara: Matser Basım.

Richter, D., Kunter, M., Ludtke, O., Klusmann, U., Anders, Y. ve Baumert, J. (2013). How different mentoring approaches affect beginning teachers' development in the first years of practice. Teaching and Teacher Education, 36, 166-177.

Searby, L. ve Tripses, J. (2012). Etkili mentorlar olabilmek için okul liderlerini hazırlama (Çev. S. Turan) Dünyada mentorluk uygulamaları (Ed. R. Yirci ve İ. Kocabaş). Ankara: Pegem Akademi.

Smith, A. (2007). Mentoring for experienced school principals: professional learning in a safe place. Mentoring and Tutoring, 15(3), 277-291.

Sundli, L. (2007). Mentoring-a new mantra for education? Teaching and Teacher Education, 23(2), 201-214.

Stephenson, J. (2009). A learning framework for novice teachers and mentors user manual for a staff development course. TISSNTE projesi yayımlanmamış kitapçığı, Faculty of Education, Community and Leisure, UK. Erişim adresi: www.tissnte.eu

Şimşek, F. (2007). Yapısal eşitlik modellemesine giriş. Ankara: Ekinoks. 
Tabachnick, B. G. ve Fidell, L. S. (2015). Çok değişkenli istatistiklerin kullanımı (Çev. Ed. M. Baloğlu). Ankara: Nobel Yayınevi.

Tavşancıl (2010). Tutumların ölçülmesi ve SPSS ile veri analizi. Ankara: Nobel Yayıncılık.

Tezbaşaran, A. (2008). Likert tipi ölçek geliştirme kılavuzu. Ankara: Psikologlar Derneği Yayınları.

Yetkiner, A. (2017). Türkiye'de aday öğretmen yetiştirme sürecinin değerlendirilmesi (Yayımlanmamış doktora tezi). Ankara Üniversitesi, Eğitim Bilimleri Enstitüsü, Ankara.

Yirci, R. ve Kocabaş, İ. (2012). Dünyada mentorluk uygulamaları. Ankara: Pegem Akademi.

Zehir Topkaya, E. ve Yalın, M. (2013). Uygulama Öğretmenliğine İlişkin Tutum Ölçeği geliştirilmesi. Eğitimde Kuram ve Uygulama, 1(1-2), 14-24. 


\section{EXTENDED ABSTRACT}

\section{Introduction}

Novice teachers face many different difficulties in their early years of teaching and need support. When we look at the pre-service teacher training process, school practice courses are crucial for teacher candidates to observe and practice teaching in a real school environment. These courses are carried out with the collaboration of universities and schools. Teacher candidates supported by academics at universities, as well as practice teachers in schools, during teaching practice courses. Therefore, the practice teachers in schools are very important in the teacher training process. Although they are very important, practice teachers may not be aware of this. Mostly they weren't able to get enough training in the mentoring process and didn't know their exact roles and duties throughout this process. On the other hand, mentoring is not just a routine process where experienced teachers share their experience. Feiman-Nemser (2001) investigated mentoring in a historical context and underlined the differences between traditional mentoring and educative mentoring. In traditional mentoring, the mentor aims to help novices to "survive" and reduce their anxiety in the early periods of work. Also, in traditional mentoring "now and here" is important, and emotional support has priority. However, in educative mentoring not only is helping to "survive" important but also improving the novice teachers' professional development and carrier. Educative mentoring serves as an individualized form of professional development as mentors begin with discussions of issues of immediate concern to a novice and help them develop alternative perspectives that lead to new solutions to difficulties (Feiman-Nemser, 2001). According to Richter et al. (2013) the teaching paradigm is different in traditional and educative mentoring. In traditional mentoring, the mentoring process is seen to be the transmission of knowledge and experiences to the novice. Novices are passive receivers. Therefore, this mentoring style can be labelled as transmissionoriented mentoring.

Practice teachers' mentoring abilities are important for their qualified support to teacher candidates. Getting enough support in teacher practices is important for teacher candidates in order to become a qualified teacher in the future. Therefore, practice teachers should have some qualifications and skills in order to accomplish this important role in teacher training process.

In this research, the aim is to develop a mentoring skills assessment tool in order to assess practice teachers' mentoring abilities.

\section{Methods}

In this study we had two study groups. Both of them were teacher candidates in their senior year who were attending the teaching practice courses and participated the school practices. In the first group there were 202 teacher candidates, and in the second group there were 232 teacher candidates. Exploratory Factor Analysis (EFA) was conducted with the data gathered from the first group and a Confirmatory Factor Analysis (CFA) was conducted with the data gathered from the second group.

The items of the tool were written according to the teaching proficiency qualifications defined by the Turkish Ministry of Education, national and international literature about mentoring and the findings of the project titled "Teacher Induction Supporting The Supporters of Novice Teachers in Europe (TISSNTE) Comenius C21". According to these sources, communication skills, teaching-learning skills, teaching methodologies, classroom management skills and feedback are considered to be important for the mentoring process and items were written in accordance with these points of reference.

The Exploratory Factor Analysis and Confirmatory Factor Analysis was applied in order to assess the validity of the tool. The Cronbach Alpha reliability value has been calculated for tool and its sub dimensions.

\section{Result}

A Tool with 66 items was applied to the first study group with 202 teacher candidates and an EFA was then conducted. As a result of the EFA, 25 items that were not discriminant at a .45 value were omitted from the tool. The tool with 41 items was applied to 232 different teacher candidates and a CFA was conducted. As 
a result of the CFA, the $t$ values of the items were meaningful at a 0.01 level and none of the item were omitted or changed. The CFI and NNFI values indicated a good model fit for the tool.

The EFA result revealed that the Mentoring Skills Assessment Tool has three sub dimensions. These dimensions can be named Teaching- Learning Process, Communication Process and Professional Development Process. Totally the tool has 41 items and in the Teaching- Learning Process dimension there are 16 items, in the Communication Process dimension there are 12 items and in the Professional Development Process dimension there are 13 items. The Cronbach Alpha reliability coefficient value was .97 for the tool. When we look at the reliability values of the sub-dimensions, it was .95 for the Teaching-Learning Process dimension, .94 for the Communication Process dimension and .89 for the Professional Development Process dimension.

\section{Conclusion}

The Mentoring Skills Assessment Tool is a reliable and valid instrument for assessing the mentoring skills of practice teachers. This tool may be used for preparing a mentor training program for practice teachers. The tool may also be used to assess the effectiveness of a mentor training program. 